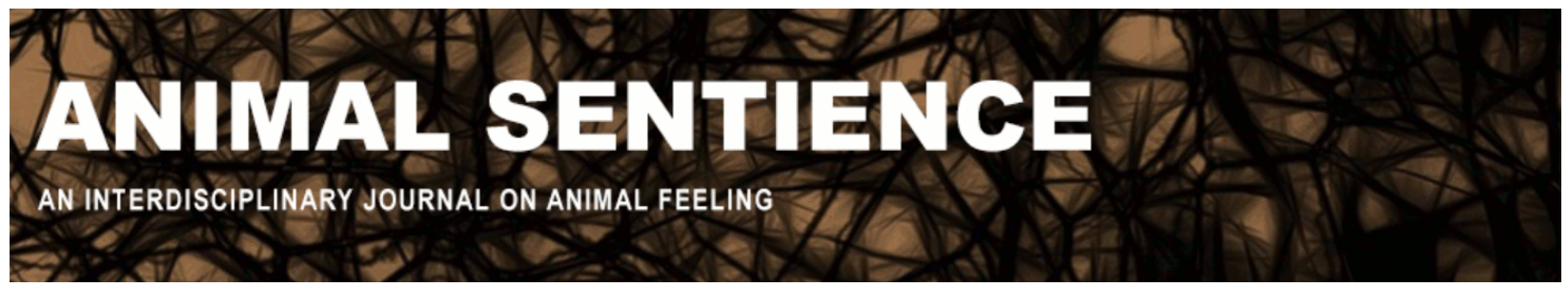

Bergstrom, Bradley J. (2020) Re-engage with the world for global health and animal welfare. Animal Sentience 30(22)

DOI: $10.51291 / 2377-7478.1651$

Date of submission: $2020-10-23$

Date of acceptance: $2020-10-29$

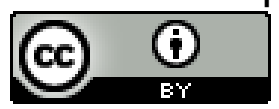

This article has appeared in the journal Animal

Sentience, a peer-reviewed journal on animal

cognition and feeling. It has been made open access,

free for all, by WellBeing International and deposited

in the WBI Studies Repository. For more information,

please contact

wbisr-info@wellbeingintl.org.

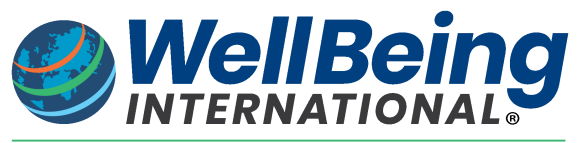

SOLUTIONS FOR PEOPLE, ANIMALS AND ENVIRONMENT 


\title{
Re-engage with the world for global health and animal welfare
}

\author{
Commentary on Wiebers \& Feigin on Covid Crisis
}

\author{
Bradley J. Bergstrom \\ Department of Biology, Valdosta State University
}

\begin{abstract}
Wiebers \& Feigin (2020) make a strong argument for measures that would limit future zoonoses, such as the COVID-19 pandemic, by closing live-animal markets, changing our habits of food consumption and production, and reducing habitat destruction. These would help human health, animal welfare, and conservation of at-risk wildlife all at the same time. China's commandand-control government can accomplish some of these things by edict, but slower-to-act western democracies play a surprisingly large role in these global problems by the power of their consumerism, including the illicit wildlife trade. We citizens need to insist that our government use all of its diplomatic soft power to engage (or re-engage) with other nations, and with global institutions such as the World Health Organization, various United Nations programs, and parties to treaties (some of which we still need to ratify, others of which we need to enforce at home) aimed at solving the interlocking global crises of species endangerment, habitat destruction, climate change, and emerging infectious disease.
\end{abstract}

Brad Bergstrom is Professor of Biology at Valdosta State University. His research interests are in higher vertebrate ecology and conservation. Website.

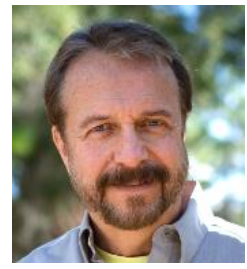

Wiebers \& Feigin (2020) (W\&F) have indeed compiled a comprehensive argument for the root causes of both the current COVID-19 pandemic (live-animal markets and illicit wildlife trade); past epidemics including HIV (bush meat); and both H5N1, or bird flu, and H1N1, or swine flu (concentrated animal feeding operations, or CAFOs, which W\&F refer to as "factory farms"); and likely future pandemics springing from large-scale land conversion dedicated to raising animals for human consumption or feed for these animals (but also, as Lee, 2020, points out in her commentary, palm-oil plantations, which yield a ubiquitous additive used in many food and nonfood consumable products). One can add to that list Ebola and the Marburg virus, which apparently emerged from Old World fruit bats in Africa (Pourrut et al. 2009). W\&F also applaud China's commitment to ending live-animal markets. I concur, both as a naïve host for whatever zoonotic is to emerge next and also as a conservationist who decries the wildlife-trade threat to pangolins, bats, and many other endangered animals being poached for these markets. Unfortunately for the wildlife, and for human health, wet markets are not the only place where wildlife is traded, nor is China the only country doing it (Massola \& Rompies 2020). For pangolins, it is the scales - not live animals - that constitute the bulk of the trade, and it may surprise readers to learn that it is the United States that is by far the largest importer of pangolin products (Heinrich et al. 2016).

W\&F then describe what "society" should do (especially, to eat lower on the food chain), but in this complex modern world of often adversarial powers asserting their autonomy, "should" and "will" are sometimes separated by a wide chasm. Lee (2020) and other commenters begin 
to prescribe solutions involving global governance frameworks such as One Health, which stress that economic - versus human and environmental-health goals should be aligned, not opposed. The World Health Organization (WHO) is the best defense humanity has against emerging diseases, and the US Centers for Disease Control (CDC) is arguably the world's premier government research agency on infectious disease. When the US President withdraws from the former and ignores the latter, the global goal of One Health becomes more unlikely, just as his withdrawal from the Paris Climate Accord and rollback of environmental regulation within the world's largest economy has made the eventuality of conquering climate change less possible. The US needs to re-engage with these international institutions. US secretaries of Interior, Commerce, State, and other Cabinet departments need to be on the same page and to present a unified front to every world leader-allies and adversaries alike-in diplomatic engagements, making it clear that we are all striving for a kinder, greener, more livable world and that the US will bring all its soft power to bear on achieving those goals.

We can only hope that the world's former environmental leader will become so again very soon, but we now know that America cannot always be counted on to save the world. So, let's look to what solutions have worked in the past. The International Whaling Commission (with some help from Greenpeace) has succeeded in stopping all but 3 countries from intentionally killing whales, and the populations of most cetaceans are rebounding (IWC 2020). The Convention on International Trade in Endangered Species of Flora and Fauna (CITES) was ratified by 80 countries in 1975, and today the number of countries party to the convention has reached 183 (CITES 2020). Speaking of potential zoonotic reservoir species, CITES lists 8 species of pangolins and 10 species of Old World fruit bats in its Appendix I, which is the highest level of recommended protection (also see Spasic 2020). Unfortunately, many countries party to CITES have not completed all the legal requirements, such as adopting laws protecting Appendix I listed species, and as the case of pangolin trade to the US illustrates, enforcement of laws that do exist is imperfect.

The World Bank and International Finance Corporation (IFC) are powerful tools for inducing good behavior among non-first-world countries, should they choose to use their power (see Park 2007). Debt-for-nature swaps were pioneered by the World Bank in collaboration with NGOs such as World Wildlife Fund in the 1980s: a portion of a country's debt was forgiven in exchange for agreements to preserve habitats of global significance, such as the Amazon rainforest (Hansen 1989). As W\&F suggest, intact biodiverse habitats are one of the best bulwarks against emerging zoonoses. The World Bank and IFC guide many other projects which now have environmental sustainability requirements, including palm oil plantations (IFC 2020) -- although I think, for the sake of orangutans and other endangered species and native forests (Gatti and Velichevskaya 2020), palm oil alternatives should be prioritized over "sustainable" palm oil, such as leaving the peanut oil in peanut butter rather than replacing it with palm oil!

It is ironic that the command-and-control communist government of China was able to quickly contain the novel coronavirus and limit its per capita infection and death rates to a degree that was orders of magnitude better than most western democracies. It is equally ironic that a totalitarian leader fighting corruption may be a more powerful force in preserving endangered species than all the CITES treaties and associated laws, which when implemented may have unanticipated negative consequences (Zhu 2020). For the capitalist-democratic societies on Earth, our strongest tools for preservation of wild animals and their habitats, and for preventing 
and ameliorating future zoonoses, include asserting our rights as citizens and voters to insist on strong government and international institutions (CDC, WHO, CITES, etc.) and to exercise our power as consumers to guide responsible practices of land use, habitat protection, and animal welfare. Those powers of citizenship and consumerism, in turn, cannot be exercised meaningfully without education. At least one recent study indicates that US undergraduate college students received failing marks on all categories of environmental literacy other than "attitude" (LloydStrovis et al. 2018). This failure represents the lack of learning and/or retention from K-12 education in the US; and despite the many fine programs (e.g., Green Schools Initiative 2020), primary and secondary education remain areas in urgent need of improvement.

\section{References}

Convention on International Trade in Endangered Species of Flora and Fauna [CITES]. (2020) Appendix I. Accessed 22 October 2020.

Gatti, R. C., \& Velichevskaya, A. (2020) Certified "sustainable" palm oil took the place of endangered Bornean and Sumatran large mammals habitat and tropical forests in the last 30 years. Science of the Total Environment 742.

Green Schools Initiative. (2020) Teach Green. Accessed 22 October 2020.

Hansen, S. (1989) Debt for nature swaps-Overview and discussion of key issues. Ecological Economics 1: 77-93.

Heinrich, S., Whitman, T. A, Prowse, T. A. A., et al. (2016) Where did all the pangolins go? International CITES trade in pangolin species. Global Ecology and Conservation 8: 241253.

International Finance Corporation [IFC]. (2020) IFC in the palm oil sector. Accessed 22 October 2020

International Whaling Commission [IWC]. (2020) Population status. Accessed 22 October 2020. Lee, K. (2020) Rethinking global governance to address zoonotic disease risks: Connecting the dots. Animal Sentience 30(19).

Lloyd-Strovis, J., Moseley, C., \& Arsuffi, T. (2018) Environmental literacy of undergraduate college students: Development of the environmental literacy instrument (ELI). School Science and Mathematics 118: 84-92.

Massola, J., \& Rompies, K. (2020) Wildlife markets are the tip of the iceberg and not just in China. The Sydney Morning Herald, 15 May 2020.

Pourrut, X., Souris, M., Towner, J.S., et al. (2009) Large serological survey showing cocirculation of Ebola and Marburg viruses in Gabonese bat populations, and a high seroprevalence of both viruses in Rousettus aegyptiacus. BMC Infectious Diseases 9: 159.

Park, S. (2007) The World Bank Group: Championing sustainable development norms? Global Governance 13: 535-555.

Spasic, V. (2020) Preventing illegal wildlife trade helps avoid zoonotic diseases. Balkan Green Energy News, 15 May 2020. Accessed 22 October 2020.

Wiebers, D. O., \& Feigin, V. L. (2020) What the COVID-19 crisis is telling humanity. Animal Sentience 30(1).

Zhu, A. L. (2020) Restricting trade in endangered species can backfire, triggering market booms. The Conversation, 13 January 2020. Accessed 22 October 2020. 